\title{
Ovine footrot in Southern Portugal: Detection of Dichelobacter nodosus and Fusobacterium necrophorum in sheep with different lesion scores
}

\author{
Catarina Albuquerque ${ }^{\mathrm{a}, \mathrm{b}}$, Sandra Cavaco ${ }^{\mathrm{a}}$, Pedro Caetano ${ }^{\mathrm{c}}$, Sandra Branco ${ }^{\mathrm{c}}$, Helena Monteiro ${ }^{\mathrm{e}}$, \\ Marcos Ramos ${ }^{\mathrm{c}, \mathrm{d}}$, Anabel Usié Chimenos ${ }^{\mathrm{c}, \mathrm{d}}$, Célia Leão ${ }^{\mathrm{a}, \mathrm{c}, \mathrm{d}}$, Ana Botelho ${ }^{\mathrm{a}, *}$ \\ ${ }^{a}$ Instituto Nacional de Investigação Agrária e Veterinária, I.P. (INIAV, I.P.), Avenida da República, Quinta do Marquês, 2780-157, Oeiras, Portugal \\ ${ }^{\mathrm{b}}$ Faculdade de Ciencias, Universidade de Lisboa, Campo Grande 016, 1749-016, Lisboa, Portugal \\ ${ }^{\mathrm{c}}$ Instituto Mediterrâneo para a Agricultura, Ambiente e Desenvolvimento (MED) \& Departamento de Medicina Veterinária, Escola de Ciências e Tecnologia, Universidade \\ de Évora, Pólo da Mitra, Apartado 94, 7006-554, Évora, Portugal \\ d Centro de Biotecnologia Agrícola e Agro-alimentar do Alentejo (CEBAL), R. de Pedro Soares, 7800-309, Beja, Portugal \\ e Associação de Agricultores do Sul (ACOS), Rua Cidade De São Paulo, Aptd. 294, Beja, Portugal
}

\section{A R T I C L E I N F O}

\section{Keywords:}

Ovine footrot

Interdigital dermatitis

Dichelobacter nodosus

Fusobacterium necrophorum

Virulence

Merino breed

\begin{abstract}
A B S T R A C T
The Mediterranean climate region of Alentejo in the Southern of Portugal is an important sheep production centre but little is known about the presence and characteristics of Dichelobacter nodosus in association with Fusobacterium necrophorum in the different footrot lesion scores. DNA from 261 interdigital biopsy samples, taken from 14 footrot affected flocks and from three non-affected flocks, were analysed for the presence of $D$. nodosus and F. necrophorum by real-time PCR. Both virulence and serogroup were determined for 132 and 53 D. nodosus positive biopsy samples, respectively. The co-infection with both bacteria was the commonest epidemiological finding associated with a greater disease severity. There was a statistically significant association $(p=0.002)$ between footrot-affected flocks and the presence of $D$. nodosus. Most $D$. nodosus positive samples were virulent (96.2\%) and belonged to serogroup B (90\%).
\end{abstract}

\section{Introduction}

Ovine footrot, due to Dichelobacter nodosus infection, is a highly contagious necrotic disease that affects hooves, with extensive economic impacts in the wool and meat industries. Disease begins as an interdigital dermatitis (ID), which may then progress to separation of the hoof horn from the underlying epidermis causing severe footrot (SFR) (Witcomb et al., 2015). The only published study in Portugal on ovine footrot was in the Alentejo region (Jiménez et al., 2003), an important Merino breed production centre, accounting for $60 \%$ of the sheep production in Portugal (Direção-Geral de Alimentação e Veterinária DGAV, 2019). Fusobacterium necrophorum has been suggested as a secondary pathogen in footrot development and, probably, in the increase of disease severity (Witcomb et al., 2014).

For the detection of these bacteria several nucleic acid based methods, more rapid and sensitive than culture, have been developed, namely PCR targeting the 16S rRNA gene (Frosth et al., 2012),

The thermostable AprV2 acidic protease, coded by aprV2 gene, is found in $D$. nodosus virulent strains while the thermolabile AprB2 acidic protease, coded by the homologous gene aprB2, is found in benign strains (Kennan et al., 2010; Stäuble et al., 2014a).

Ten serogroups (A-I and $\mathrm{M}$ )) have been identified in D. nodosus (Dhungyel et al., 2002; Ghimire et al., 1998) based on variations in the carboxy-terminal region of the IV fimbriae subunit, and a serogroup-specific PCR assay (Dhungyel et al., 2002) targeting the fim $A$ gene can discriminate nine serogroups (A-I). The identification of the predominant serogroups is the first step towards better control of the disease, through the use of both adequate prophylactic vaccines and improved biosafety measures. Additionally, prophylactic vaccines have been considered an adequate approach to footrot prevention and flock-specific vaccines has been proposed as a more efficient alternative to the multivalent commercial vaccines (Caetano et al., 2018). This work aims to detect $D$. nodosus and $F$. necrophorum in Alentejo sheep flocks, with different ovine footrot lesion scores, and to characterize $D$ nodosus with respect to virulence and serogroup.

\footnotetext{
* Corresponding author.

E-mail address: ana.botelho@iniav.pt (A. Botelho).
} 


\section{Materials and methods}

\subsection{Sheep flocks and sampling procedure}

From 13 different geographical counties in the Southern Portuguese Alentejo region (Fig. 1), 17 sheep flocks of crossbreed Merino, were selected among 689 flocks, based on epidemiological inquires to evaluate the presence of footrot in the region. The selection criteria included presence of clinical cases of footrot in the last 2 years; flocks with no less than 100 autochtone cross bread Merino sheep; no treatment for footrot within the last 30 days before sampling; availability and collaboration of the farmer. The four sheep feet were examined for footrot lesions by three DVM with large experience and training in this clinical diagnostic. Based on the Modified Egerton System (Buller and Eamens, 2014) the lesions were scored from 0 to 5 , according to the extent of the lesion, as follows: score 0 - normal foot with no lesions; score 1 - limited interdigital dermatitis; score 2 - more extensive interdigital dermatitis involving part or all of the soft horn; score 3 - more extensive interdigital dermatitis with separation at the skin horn junction, extending across the heel or sole; score 4 - separation at the skin horn junction extending to the walls and outside edge of the foot; score 5 - necrotic inflammation of the deeper tissue with separation of hard horn of the foot.

Interdigital skin punch biopsies $(n=261)$ were collected from one foot of each animal, using disposable sterile Biopsy Punches $(6 \mathrm{~mm}$ diameter) as described by Witcomb et al., 2015. Chlorhexidine solution $(10 \mathrm{mg} / \mathrm{mL})$ and lidocaine (Anestesin $\left.{ }^{\circledR}\right)$ were applied, respectively, for local cleaning and anaesthesia. From each lesion scores the following samples were collected: score $0 \mathrm{n}=84$, score $1 \mathrm{n}=48$, score $2 \mathrm{n}=49$, score $3 \mathrm{n}=59$, score $4 \mathrm{n}=19$ and score $5 \mathrm{n}=2$. Samples were immediately frozen in liquid nitrogen and kept at $-20{ }^{\circ} \mathrm{C}$ until being processed.

The 17 flocks, identified from A to Q, were classified in four categories (1-4) according to the criteria of Frosth et al., 2015: category 1 majority of animals with score 0 and no animal with score above 1 ; category 2 - predominance of animals with score 1 and no animal with score above 1 ; category 3 - at least one animal with score 2 ; category 4 at least one animal with score 3 . Symbols representing each flock category are indicated in Fig. 1.

\subsection{Reference strains}

The reference strains $D$. nodosus CCUG 27824T and F. necrophorum subsp. necrophorum CCUG $9994 \mathrm{~T}$ (Culture Collection University of Gothenburg, Sweden) were used as controls. Nine D. nodosus DNA samples from serogroups A to I, used as positive controls in the serogrouping assays, were acquired to Dr. O. P. Dhungyel, University of Sydney, Australia.

\subsection{Detection of D. nodosus and F. necrophorum DNA in biopsy samples by real time $P C R$}

DNA was extracted, from $25 \mathrm{mg}$ of 261 biopsy samples, using QIAamp ${ }^{\circledR}$ cador ${ }^{\circledR}$ Pathogen Mini Kit $+\mathrm{T} 2$ pre-treatment (Qiagen no. 50214) according to manufacturer instructions.

Detection and identification of $D$. nodosus and $F$. necrophorum was performed by real time PCR targeting, respectively, 16S rRNA (Frosth

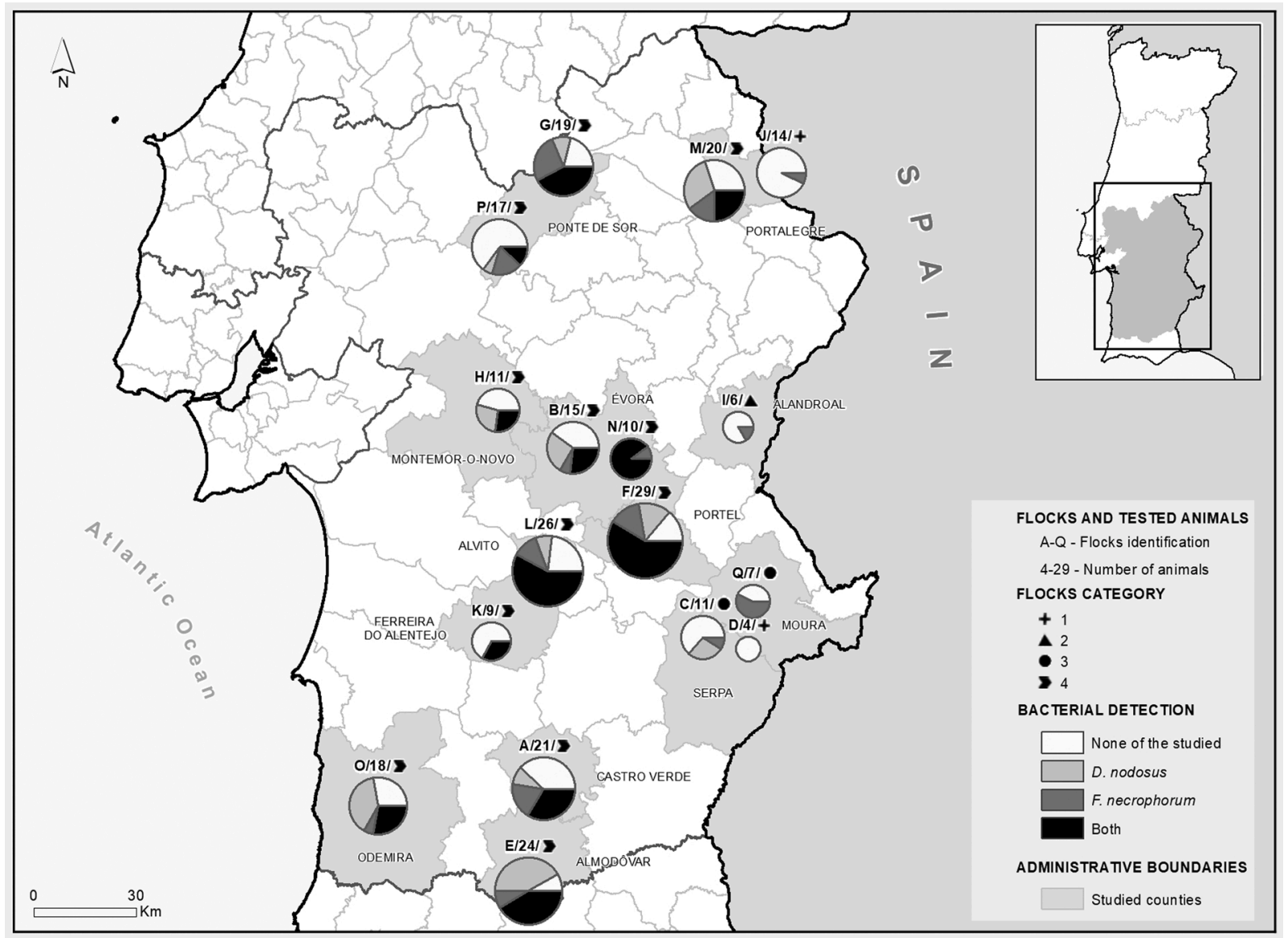

Fig. 1. Location of the 17 studied flocks in the 13 selected counties of the Alentejo region. Identification of flocks (A to Q), number of sheep tested and symbol correspondent to the flock category ( 1 to 4 ) are indicated on the top of each pie graph that marks the location of the flock. The size of this pie graph is proportional to the number of animals tested in each flock and shades of sectors corresponds to the percentage of bacterial detection (none, only Dichelobacter nodosus, only Fusobacterium necrophorum or both), according to information on the right end corner of the map. 
et al., 2012) and rpoB (Witcomb et al., 2014) genes, according to author's description, using a Bio-Rad CFX96 system and QuantiFast Pathogen Master Mix (Qiagen no. 211354).

\subsection{Determination of $D$. nodosus virulence}

$D$. nodosus positive biopsy samples were analysed by competitive real-time PCR method targeting the aprV2/B2 gene, according to Stäuble et al. (2014a), to discriminate between benign and virulent determinants. Sanger sequencing of a PCR amplified aprV2/B2 fragment of 436 bp (Stäuble et al., 2014b) was performed (GATC, Eurofins Genomics) to confirm the real-time PCR results.

Sequences identity matching was carried out using Basic Local Alignment Search Tool (BLAST) (blast.ncbi.nih.gov/Blast.cgi) and edited with the BioEdit Sequence Alignment Editor (Ibis Therapeutics, Carlsbad, USA) (Hall, 1999). The ClustalX2 software (Conway Institute UCD Dublin, Ireland) was used to align sequences against the reference aprV2 nucleotide sequence from the virulent strain A198 (accession no. L38395) and the reference aprB2 nucleotide sequence from the benign strain C305 obtained from GenBank (accession no. FN674446).

\subsection{Determination of D. nodosus serogroups}

To determine serogroup affinity (A-I), a multiplex PCR system targeting the fimA gene, described by Dhungyel et al. (2002), was performed, on positive $D$. nodosus biopsy samples, selected in each flock from sheep with lesion scores 1-5. A forward primer, common to all nine serogroups, and nine reverse primers, specific to each serogroup were used. Combinations of three serogroup specific reverse primers (ABC, DEF or GHI) were used in each multiplex PCR as suggested by Dhungyel et al. (2002). The reactions were carried out in a Biometra TOne Thermal Cycler (Analytik Jena, US) using the same conditions as described by the same authors. PCR products were visualized through $2 \%(\mathrm{w} / \mathrm{v})$ agarose gel electrophoresis at $100 \mathrm{~V}$ for $60 \mathrm{~min}$ and imaging collected using the UVP BioDoc-It ${ }^{\circledR}$ Imaging System (Analytik Jena, US).

\subsection{Statistical analysis}

Descriptive statistic was used to calculate proportions of different bacterial findings at flock and individual levels. These were performed using Microsoft Excel for Office 365. Fisher's Exact Test was used to analyse the connections between flock categories (1-4) and D. nodosus and $F$. necrophorum presence (yes/no). This test was performed using IBM SPSS Statistics for Windows, version 26.0 (Armonk, NY: IBM Corp).

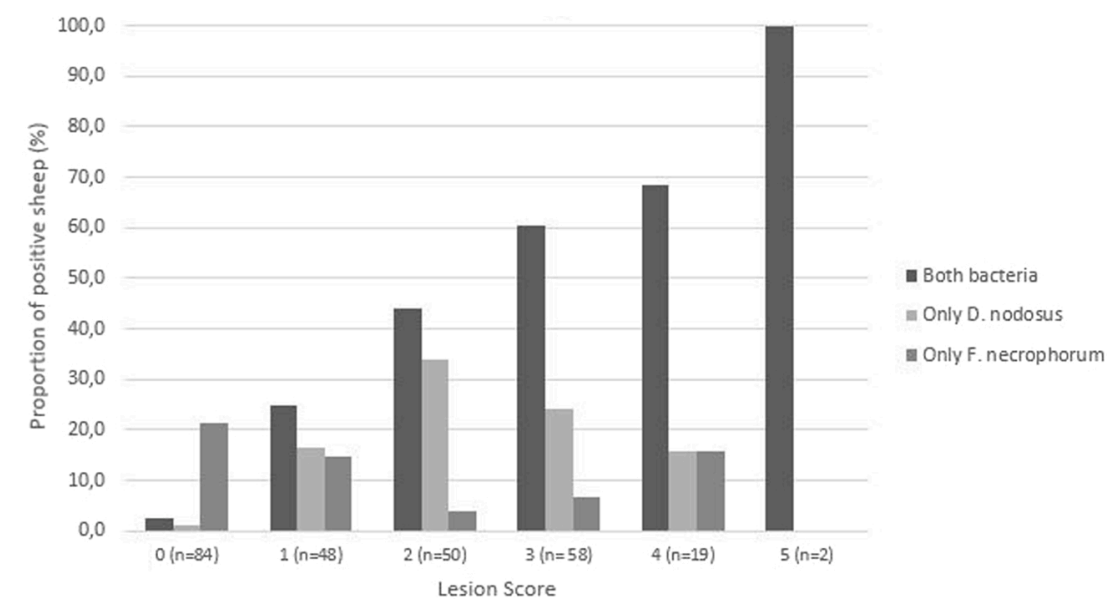

\subsection{Geospatial analysis}

To display, explore and edit GIS datasets of the studied region, to assigned symbols and to create map layouts about the distribution and characteristics of footrot within each flock geographic region, ArcMAP software version 10.8.1 (ArcGIS) was used.

\section{Results}

\subsection{Detection of D. nodosus and F. necrophorum DNA in biopsy samples}

Considering a cycling threshold $(\mathrm{Ct})<40$ the cut-off value for the presence of $D$. nodosus or $F$. necrophorum, the Ct values of positive samples ranged between 31.28 and 39.31. Samples with a lesion score 1-5 showed always the presence of both D.nodosus and $F$. necrophorum (Fig. 2), with a predominance that ranged from $25 \%$ in lesion score $1-100 \%$ in lesion score 5 , corresponding to severe footrot (SFR). D. nodosus alone was detected on $1.2 \%$ of healthy feet, $25.5 \%$ average of feet with interdigital dermatitis ID (scores 1 and 2) and $21.5 \%$ average of feet with more severe footrot lesions (scores 3 and 4). $F$ necrophorum alone was detected in $21.4 \%$ of healthy feet, $9.2 \%$ average of feet with ID (scores 1 and 2) and $8.86 \%$ average of feet with more severe footrot lesions (scores 3 and 4). F. necrophorum was present in a lower percentage (6.9\%) than D. nodosus $(24.1 \%)$ in lesion score 3 , but had the same percentage as D. nodosus in lesion score 4 (15.8 \%) (Fig. 2).

Considering the flock (Fig. 1) category from 0 to $4, D$. nodosus was detected only in severe footrot-affected flocks (categories 3 and 4) showing a significant association $(p=0.002)$ between footrot and the presence of this bacteria. On the other hand, F. necrophorum was detected in both footrot-affected flocks (categories 3 and 4) and in clinically healthy flocks (categories 1 and 2) and there was no significant association between flock category and detection of this bacteria ( $p=$ 0.294).

The flocks with higher $F$. necrophorum infection rate (Fig. 1) were flocks N (100\%), F (69\%), L (69\%), and G (68\%) and the ones with lower infection rate were flocks D (0\%), C (9\%), J (7 \%) and I (17 \%). $D$. nodosus was present in all but two locations (Alandroal and Moura) of the 13 studied counties (Fig. 1), with the highest presence in Almodôvar (83\%), Portel (72.4\%) and Évora (68\%).

\subsection{D. nodosus virulence and serogroup}

From the total of $132 \mathrm{D}$. nodosus positive biopsy samples, 127 (96.2 $\%$ ) revealed the presence of the aprV2 gene, coding for the thermostable AprV2 protein that is considered to confer virulence. This result was confirmed by sequencing the $436 \mathrm{bp}$ amplified fragment of this gene. In five samples no amplification was obtained.

Fig. 2. Presence of Dichelobacter nodosus, Fusobacterium necrophorum or both bacteria in the different footrot lesion scores 0 to 5 : score 0 - healthy foot with no lesions; score 1 - limited interdigital dermatitis; score 2 - more extensive interdigital dermatitis; score 3 - more extensive interdigital dermatitis with separation at the skin horn junction; score 4 - separation at the skin horn junction extending to the walls and outside edge of the foot; score 5 - necrotic inflammation of the deeper tissue with separation of hard horn of the foot. 
Serogroups B ( $90 \%)$, C (5\%) and F (5\%) were identified in 19 out of 53 D. nodosus positive biopsy samples.

\section{Discussion}

The population pattern of $D$. nodosus, along with the presence of F. necrophorum, were analysed with respect to the different footrot lesion scores observed in sheep from the Alentejo region. From our results the percentage of co-infections with these two bacteria increased from score 3 to 5 , while in the absence of lesions (healthy feet - score 0) $F$. necrophorum predominated. An increase of $D$ nodosus was observed from mild lesions (scores 1 and 2) to more severe lesions. Besides, in healthy feet (score 0 ) the low $D$. nodosus detection (4\%) and the high F. necrophorum detection ( $24 \%$ ) suggests that this latter bacterium may not have the ability to cause the disease, what corroborates previous observations (Roberts and Egerton, 1969; Witcomb et al., 2014).

Analysis at the flock level confirms these findings. All category 4 flocks present co-infection with $D$. nodosus and $F$. necrophorum, while in category 1, 2 and 3 flocks (flocks D/4, J/14, I/6, C/11 and Q/7) coinfection with $D$. nodosus and $F$. necrophorum was not observed. Apart from healthy flock D, category 1 or 2 flocks I, J and Q, were only infected with $F$. necrophorum. These flocks could benefit from bio sanitary measures to avoid infection with $D$. nodosus and the progression to footrot (Caetano et al., 2018). It seems that hotspots of footrot exist in the surrounding area of Évora (flocks N, F and L) since the highest percentage of $D$. nodosus/F. necrophorum co-infection was detected there. The average temperature and precipitation in the Alentejo region, when samples were collected, varied between $15.5-16.5{ }^{\circ} \mathrm{C}$ and $548-701.3$ $\mathrm{mm} / \mathrm{m}^{2}$, respectively (Caetano, P., personal information). Serpa (flocks $\mathrm{C}$ and D), Moura (flock Q) and Alandroal (flock I) were the driest counties and, as expected, also the ones less infected, since wet conditions favours the development of footrot. In fact, the best environmental conditions for the development of the disease are warm and wet climate (Muzafar et al., 2016), as occurred in Évora (flock N), Portel (flock F) and Alvito (flock L) counties with an average temperature and precipitation of $15.5^{\circ} \mathrm{C}$ and $701.3 \mathrm{~mm} / \mathrm{m}^{2}$, respectively.

Most $D$. nodosus positive biopsy samples tested were virulent (96.2 $\%$ ), as expected since they were from affected sheep with footrot lesion scores $1-5$, and 19 out of 53 belonged to the serogroup B. The serogroup of $34 \mathrm{D}$. nodosus positive biopsy samples were undetermined using the multiplex PCR, possibly because they belong to the serogroup M or to another yet unknown serogroup not targeted in this PCR. Serogroup B was also the most frequently found in New Zealand, United Kingdom and India (Caetano et al., 2018; Wani et al., 2019). However, in nearby Spain serogroups A and C were the most commonly detected by slide microagglutination technique (Hurtado et al., 1998). In Alto Alentejo region (Montemor-o-Novo, Évora, Alandroal counties and above) Jiménez et al. (2003), using the microagglutination technique, identified, predominantly, serogroups D, F and I (14.5 \% each), while in this region we identified serogroups $\mathrm{B}$ and $\mathrm{C}$. The only common serogroups identified in both works were serogroups $\mathrm{D}$ and $\mathrm{F}$ in flock F located in Portel, Baixo Alentejo. The existence of more than one serogroup in the same flock was frequent, with the exception of flocks $\mathrm{M}, \mathrm{N}$ and $\mathrm{O}$ with single serogroups. These findings provide valuable information for the development of immunoprophylactic methods, such as herd-specific vaccines, which are made from the isolated microorganisms in the region and are more efficient than multivalent commercial vaccines (Caetano et al., 2018).

\section{Ethical approval}

This study was approved by the ethics committee for animal experimentation ORBEA-U Évora, Portugal (ID: GD/20467/2021/P1).

\section{Declaration of Competing Interest}

No competing interests to declare.

\section{Acknowledgements}

This work was supported by project "GEN-RES Alentejo - Use of genomics methodologies to assist selection of sheep resistant to footrot and gastrointestinal nematodes in the Alentejo region." (REF: ALT20-030145-FEDER-000037). Thanks are due to Dr. Sara Frosth (SVA, Uppsala, Sweden) for fruitful discussions and suggestions and to João Fernandes (INIAV) for technical assistance in preparation of Fig. 1 using the ArcMAP system. The authors are grateful to Dr. Robin Nicholas (Weybridge, UK) for careful correction of English writing and to the anonymous referees for their contributions to the improvement of the manuscript.

\section{References}

Buller, N., Eamens, G., 2014. Ovine footrot. Aquatic and Terrestrial Australian and New Zealand Standard Diagnostic Procedures (ANZSDPs).

Caetano, P., Bettencourt, E.V., Branco, S., 2018. Reviewing footrot in sheep. J. Vet. Sci. Anim. Husb. 6, 405-413.

Dhungyel, O.P., Whittington, R.J., Egerton, J.R., 2002. Serogroup specific single and multiplex PCR with pre-enrichment culture and immuno-magnetic bead capture for identifying strains of $D$. nodosus in sheep with footrot prior to vaccination. Mol. Cell. Probes 16, 285-296. https://doi.org/10.1006/mcpr.2002.0427.

Direção-Geral de Alimentação e Veterinária (DGAV), 2019. Número de Animais e explorações (Number of Animals and Animal Facilities). Portugal.

Frosth, S., Slettemeås, J.S., Jørgensen, H.J., Angen, Ø., Aspán, A., 2012. Development and comparison of a real-time PCR assay for detection of Dichelobacter nodosus with culturing and conventional PCR: harmonisation between three laboratories. Acta Vet. Scand. 54, 1-7. https://doi.org/10.1186/1751-0147-54-6.

Frosth, S., König, U., Nyman, A.K., Pringle, M., Aspán, A., 2015. Characterisation of Dichelobacter nodosus and detection of Fusobacterium necrophorum and Treponema spp. in sheep with different clinical manifestations of footrot. Vet. Microbiol. 179, 82-90. https://doi.org/10.1016/j.vetmic.2015.02.034.

Ghimire, S., Egerton, J., Dhungyel, O., Joshi, H., 1998. Identification and characterisation of serogroup M among Nepalese isolates of Dichelobacter nodosus, the transmitting agent of footrot in small ruminants. Vet. Microbiol. 62 (3), 217-233.

Hall, T.A., 1999. BioEdit: a user-friendly biological sequence alignment editor and analysis program for windows 95/98/NT. Nucleic Acids Symp. Ser. 45, 95-98.

Hurtado, M.A., Píriz, S., Valle, J., Jimenez, R., Vadillo, S., 1998. Aetiology of ovine footrot in Spain. Vet. Rec. 142, 60-63. https://doi.org/10.1136/vr.142.3.60.

Jiménez, R., Píriz, S., Martín-Palomino, P., Mateos, E., Vadillo, S., 2003. Aetiology of ovine footrot in the Portuguese region of Alto Alentejo. J. Vet. Med. Ser. B 50, 118-120. https://doi.org/10.1046/j.1439-0450.2003.00645.x.

Kennan, R.M., Wong, W., Dhungyel, O.P., et al., 2010. The subtilisin-like protease AprV2 is required for virulence and uses a novel disulphide-tethered exosite to bind substrates. PLoS Pathog. 6 (11), e1001210.

Muzafar, M., Green, L.E., Calvo-Bado, L.A., Tichauer, E., King, H., James, P., Wellington, E.M.H., 2016. Survival of the ovine footrot pathogen Dichelobacter nodosus in different soils. Anaerobe 38, 81-87. https://doi.org/10.1016/j. anaerobe.2015.12.010.

Roberts, D.S., Egerton, J.R., 1969. The aetiology and pathogenesis of ovine foot-rot. II The pathogenic association of Fusiformis nodosus and F. necrophorus. J. Comp. Pathol. 79, 217-226.

Stäuble, A., Steiner, A., Frey, J., Kuhnert, P., 2014a. Simultaneous detection and discrimination of virulent and benign Dichelobacter nodosus in sheep of flocks affected by footrot and in clinically healthy flocks by competitive real-time PCR. J. Clin. Microbiol. 52, 1228-1231. https://doi.org/10.1128/JCM.03485-13.

Stäuble, A., Steiner, A., Normand, L., Kuhnert, P., Frey, J., 2014b. Molecular genetic analysis of Dichelobacter nodosus proteases AprV2/B2, AprV5/B5 and BprV/B in clinical material from European sheep flocks. Vet. Microbiol. 168, 177-184. https:// doi.org/10.1016/j.vetmic.2013.11.013.

Wani, S.A., Farooq, S., Kashoo, Z.A., Hussain, I., Bhat, M.A., Rather, M.A., Aalamgeer, S., 2019. Determination of prevalence, serological diversity, and virulence of Dichelobacter nodosus in ovine footrot with identification of its predominant serotype as a potential vaccine candidate in J\&K, India. Trop. Anim. Health Prod. 51, 1089-1095. https://doi.org/10.1007/s11250-018-01788-9.

Witcomb, L.A., Green, L.E., Kaler, J., Ul-Hassan, A., Calvo-Bado, L.A., Medley, G.F., Grogono-Thomas, R., Wellington, E.M.H., 2014. A longitudinal study of the role of Dichelobacter nodosus and Fusobacterium necrophorum load in initiation and severity of footrot in sheep. Prev. Vet. Med. 115, 48-55. https://doi.org/10.1016/j. prevetmed.2014.03.004.

Witcomb, L.C., Green, L.E., Calvo-Bado, L.A., Russell, C.L., Smith, E.M., GrogonoThomas, R., Wellington, E.M.H., 2015. First study of pathogen load and localisation of ovine footrot using fluorescence in situ hybridisation (FISH). Vet. Microbiol. 176, 321-327. https://doi.org/10.1016/j.vetmic.2015.01.022. 